\title{
PENINGKATAN HASIL BELAJAR MATEMATIKA SISWA SMA MELALUI PEMBELAJARAN GUIDED INQUIRY
}

\author{
Puji Hartati \\ Guru SMA Negeri 1 Bengkulu Tengah \\ pujihartati0878@gmail.com
}

\begin{abstract}
Abstrak
Penelitian ini bertujuan untuk meningkatkan hasil belajar matematika siswa kelas X SMA Negeri 1 Bengkulu Tengah dengan model pembelajaran quided inquiry. Peningkatan difokuskan pada materi penerapan trigonometri dalam masalah nyata. Penelitian yang dilaksanakan merupakan penelitian tindakan kelas (PTK). Penelitian ini dilaksanakan dalam dua siklus dengan empat tahapan, yaitu: (1) perencanaan, (2) pelaksanaan, (3) pengamatan, dan (4) refleksi. Subjek penelitian adalah siswa kelas X-IBB SMA Negeri 1 Bengkulu Tengah yang berjumlah 24 orang siswa. Instrumen penelitian yang digunakan adalah instrumen tes yang mengukur kompetensi materi trigonometri. Teknik pengumpulan data dalam penelitian ini adalah menggunakan teknik observasi dan tes. Hasil penelitian menunjukkan terjadi peningkatan hasil belajar matematika siswa. Data pra siklus menunjukkan ketuntasan siswa sebesar 33,33\% dan meningkat drastis pada siklus II yaitu mencapai 54,17\%. Pada akhir siklus II ketuntasan klasikal siswa mencapai 83,33\%. Peningkatan hasil belajar tersebut disebabkan adanya perbaikan proses pembelajaran yang didasarkan refleksi pada akhir siklus dengan mengacu tahapan pembelajaran quided inquiry.
\end{abstract}

Kata Kunci: Quided Inquiry, Hasil Belajar, Penelitian Tindakan Kelas

\begin{abstract}
The aim of this research was to improve student mathematics learning outcome of Grade X Senior High School Number 01 Central Bengkulu with guided inquiry learning model. Improving was foccuss on applying trigonometry in the real problem. This research was classroom action research (CAR). This research did in two cycles with the steps were: (1) planning, (2) acting, (3) observing, and (4) reflecting. Subject of this research was 24 students grade X-IBB Senior High School Number 01 Central Bengkulu. instrument of this research was instrument to measure trigonometry compentence. Data collection techniques in this research were observation and test. Student learning outcome showed that there was improving of student mathematics learning outcome. Pre cycle data showed that sudent classical pass $33,33 \%$ and increased dramatically in second cycle $54,17 \%$. In the end of second cycle, student classical pass reached 83,33\%. Improving of student learning outcome happened because of repairing of learning process by reflecting in the end of every cycles.
\end{abstract}

Keyword : Quided Inquiry, Learning Outcome, Classroom Action Research.

\section{PENDAHULUAN}

Matematika menjadi salah satu mata pelajaran yang dijadikan tolok ukur dalam mengukur kemampuan pada setiap jenjang pendidikan. Sebagai contoh, mata pelajaran matematika merupakan mata pelajaran yang di UN kan pada tingkat SD, SMP, dan SMA. Selain itu, seleksi perguruan tinggi mewajibkan calon mahasiswa untuk menguasai salah satu bidang yaitu matematika dalam memilih perguruan tinggi yang diiginkan. Hal ini menjadikan matematika menjadi salah satu mata pelajaran yang sangat penting untuk dikuasai peserta didik.
Dalam upaya mempersiapkan siswa menguasai pelajaran matematika maka diperlukan desain pembelajaran yang dapat memberikan ruang siswa dalam belajar. Pembelajaran yang kurang tepat dilakukan di kelas akan berimbas pada pencaiapan tujuan pembelajaran. Materi pada pembelajaran matematika memiliki karakteristik yang berbedabeda. Namun, dalam pelaksanaan pembelajaran guru cendrung memberikan perlakuan yang sama sehingga pembelajaran belum dapat memfokuskan pada penguasaan materi tertentu. Melalui pembelajaran matematika, siswa diharapkan 
memiliki kemampuan berpikir logis, analitis, sistematis, kritis, dan kreatif, serta memiliki kemampuan bekerja sama (Depdiknas, 2006).

Pentingnya matematika dikuasai oleh peserta didik salah satunya siswa SMA menjadikan tuntutan dan tantangan bagi setiap elemen sekolah dalam meningkatkan ketercapaian hasil pembelajaran. Berbagai upaya telah dilakukan oleh pihak terkait, salah satunya pemerintah dengan menerapka kurikulum 2013. Implementasi kurikulum 2013 memfokuskan pada keaktifan siswa dengan pembelajaran berbasis model pembelajaran terpusat siswa. Salah satu tujuan pembelajaran matematika di jenjang SMA adalah memahami konsep matematika, menjelaskan keterkaitan antar konsep dan mengaplikasikan konsep atau algoritma, secara luwes, akurat, efisien, dan tepat, dalam pemecahan masalah (Kemendikbud, 2014).

Kenyataan pada pembelajaran di sekolah menunjukkan bahwa ketercapaian tujuan pembelajaran khususnya matematika masih perlu ditingkatkan. Sebagai contoh, hasil survei awal peneliti sebagai guru kelas X SMA dengan memberikan soal ulangan harian materi perbandingan trigonometri. Hasil tes siswa dengan menggunakan skor dengan skala penilaian rentang 0-100 dideskripsikan seperti tabel berikut.

Tabel 1.

Hasil Ulangan Harian siswa Kelas X-IBB SMA

\begin{tabular}{|r|c|c|}
\multicolumn{3}{|c}{ Negeri 1 Bengkulu Tengah } \\
\hline Rentang & Banyak Siswa & Persentase (\%) \\
\hline $0-20$ & 2 & 8.33 \\
\hline $21-40$ & 4 & 16.67 \\
\hline $41-60$ & 11 & 45.83 \\
\hline $61-80$ & 6 & 25.00 \\
\hline $81-100$ & 1 & 4.17 \\
\hline
\end{tabular}

Hasil ulangan tersebut menunjukkan perlu adanya perbaikan proses pembelajaran agar ketercapaian pembelajaran dapat lebih maksimal. Berbagai upaya yang dapat dilakukan dianataranya merancang pembelajaran di kelas dengan menggunakan model atau pendekatan pembelajaran yang tepat.

Dalam merancang pembelajaran pemilihan model atau pendekatan pembelajaran menjadi kunci utama keterlaksanaan pembelajaran. Salah satu model pembelajaran yang dapat digunakan adalah model Guided Inquiry. Menurut Abidin (2013) model pembelajaran Inquiry dirasa cocok karena dapat membantu siswa memperoleh kompetensi meneliti dan kompetensi pengetahuan yang disertai pula dengan kompetensi pemahaman, kompetensi menulis, kompetensi bekerja sama, kompetensi berpikir kritis kreatif dan inovatif sekaligus mampu digunakan untuk mengembangkan minat dan motivasi belajar. Guided inqury pada umumnya menekankan pertanyaan-pertanyaan dan ide-ide yang memotivasi siswa untuk ingin belajar lebih banyak dan menciptakan cara-cara untuk membagikan apa yang telah mereka pelajari (Kuhlthau et al, 2007).

Berdasarkan kajian tersebut, maka perlu dilaksanakan penelitian yang didesain dnegan menggunakan model pembelajaran quided inquiry untuk meningkatkan hasil belajar siswa. Menurut Joyce dan Weil (1992) dengan model tersebut guru dapat membantu siswa mendapatkan atau memperoleh informasi, ide, ketrampilan, cara berpikir, dan mengekspresikan ide diri sendiri.

Tahapan pelaksaan pembelajaran mengacu pada langkah model pembelajaran guided inquiry sebagai berikut (Moore, 2009)

1. Langkah 1: Engage

Siswa mengidentifikasi tugas pembelajaran. Kegiatan ini menarik perhatian siswa dan merangsang pemikiran mereka. Pertanyaanpertanyaan diajukan, hubungan antara pengalaman belajar masa lalu dan sekarang dibuat, dan masalah didefinisikan.

2. Langkah 2: Explore

Siswa terlibat secara langsung dalam kegiatan dan materi. Mereka mengembangkan dasar pengalaman dalam kegiatan. Siswa mengidentifikasi dan mengembangkan konsep, proses, dan keterampilan. Mereka secara aktif mengeksplor lingkungannya atau memanipulasi materi.

3. Langkah 3: Explain

Siswa terlibat dalam menganalisis eksplorasinya dan mengubah pengalaman yang abstrak ke dalam bentuk yang lebih mudah. Siswa mempunyai keuntungan untuk memverbalkan pemahaman konseptualnya dan mendemonstrasikan kemampuan atau sikap yang baru. Pemahaman siswa diklarifikasi dan dimodifikasi karena kegiatan refleksi.

4. Langkah 4: Elaborate

Siswa memperluas konsep yang mereka pelajari, membuat hubungan-hubungan dengan konsepkonsep lain yang saling berhubungan, dan menerapkan pemahaman mereka ke lingkungan siswa. Hubungan-hubungan ini sering 
memunculkan penemuan dan pemahaman yang baru.

5. Langkah 5: Evaluate

Guru menentukan apakah siswa telah mencapai pemahaman konsep dan pemahaman pengetahuan. Evaluasi dan penilaian dapat terjadi pada semua titik selama proses pembelajaran berlangsung.

Beberapa kajian empiris menunjukkan bahwa adanya dampak positif dari pembelajaran yang menggunakan model quided inquiry. Hasil penelitian yang telah dilakukan oleh Sefriyan, Ceswita, dan Coesamin (2013) menunjukkan bahwa adanya pengaruh pengaruh penerapan Metode inkuiri terbimbing terhadap motivasi, aktivitas siswa SMP. Metode inkuiri terbimbing memiliki keunggulan yaitu berpengaruh positif terhadap motivasi, aktivitas, dan hasil belajar siswa. Sejalan dengan hal tersebut, hasil penelitian yang dilakukan oleh Rusdi, Maulidiya, \& Susanto (2013) menunjukkan bahwa model Inquiry terbimbing dapat meningkatkan hasil belajar dan aktivitas siswa SMA dalam pembelajaran geometri.

Penelitian terdahulu telah dilakukan dan menunjukkan adanya dampak penerapan pembelajaran quided inquiry terhadap hasil belajar matematika. Penelitian terdahulu difokuskan pada peningkatan motovasi, aktivitas dan hasil pembelajaran siswa. Berbeda dengan penelitian yang dilakukan adalah subjek yang menjadi sasaran adalah siswa SMA dimana dalam menerapkan penyelidikan siswa SMA lebih dapat mengeksplorasikan kemampuan dalam matematika. Selain itu, dalam penelitian juga memfokuskan pada materi penerapan trigonometri dalam kehidupan nyata.Hal ini menunjang pada tahapan penyajian masalah pada tahapan model quided inquiry.

Penelitian ini bertujuan untuk mengetahui bagaimana penerapan model pembelajaran quided inquiry sehingga dapat meningkatkan hasil belajar siswa. Pembelajaran difokuskan pada materi penerapan trigonometri.

\section{METODE PENELITIAN}

Penelitian yang dilaksanakan merupakan penelitian tindakan kelas. Pelaksanaan penelitian melalui empat tahapan penelitian yang di adaptasi dari Suhardjono (Arikunto, 2009), yaitu: (1) tahap perencanaan, (2) tahap pelaksanaan tindakan, (3) tahap engamatan, dan (4) tahap refleksi. Tahapan tersebut dilaksanakan dalam dua siklus pembelajaran yang dilakukan untuk mengetahui peningkatan hasil belajar siswa. Prosedur penelitian seperti di gambarkan berikut. (Iskandar, 2009).

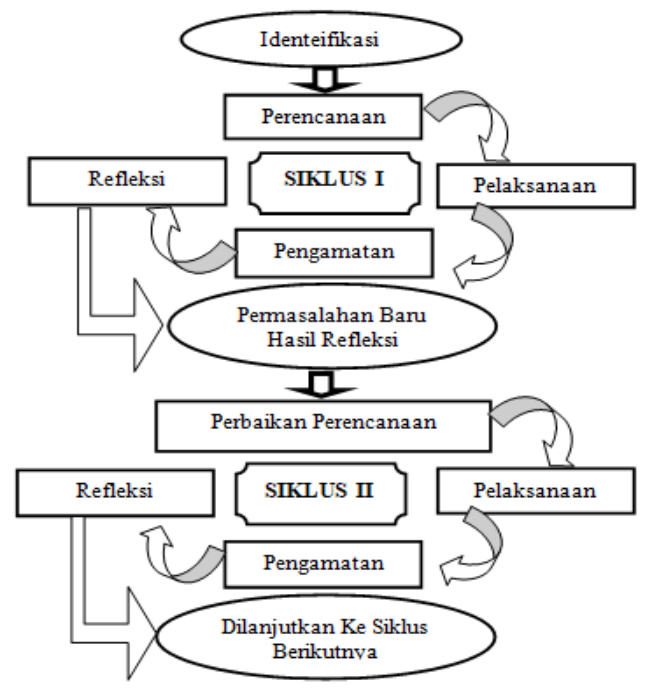

Gambar 1. Prosedur Pelaksanaan PTK

Subjek yang diamati dalam pelaksanaan penelitian ini adalah siswa Kelas X-IBB SMA Negeri 1 Bengkulu Tengah. Jumlah siswa yang menjadi subjek penlitian sebanyak 24 orang dengan 15 orang siswa perempuan dan 9 siswa laki-laki. Teknik pengumpulan data yang digunakan adalah teknik observasi dan tes. Instrumen uanh digunakan dalam penelitian ini adalah instrumen tes hasil belajar yang merupakan soal uraian.

Teknik analisis data dilakukan dengan menghitung rata-rata hasil belajar siswa dan ketuntasan belajar klasikal siswa yang dinyatakan dalam perentase. Kriteria keberhasilan tindakan dalam penelitian ini adalah persentase ketuntasan belajar klasikal (nilai lebih dari KKM) setiap siklus meningkat dan akhir siklus mencapai $80 \%$.

\section{HASIL DAN PEMBAHASAN \\ a. Hasil Penelitian}

Pelaksanaan penelitian diawali dengan memberikan tes kepada siswa yang bertujuan untuk mengukur kemampuan awal siswa sebelum diberikan tindakan. Tes diberikan dengan menggunakan soal uraian tentang perbandinggan trigonometri pada sudut istimewa. Hasil tes dijadikan salah satu acuan dalam memberikan tindakan dan pembagian kelompok dalam belajar.

Tahapan selanjutnya dilakukan pemberian tindakan dengan menggunakan model quided inquiry. Pelaksanaan penelitian dilakukan dalam dua siklus dengan setiap siklus dilakukan empat tahapan PTK, yaitu: (1) tahap perencanaan, (2) tahap 
pelaksanaan tindakan, (3) tahap engamatan, dan (4) tahap refleksi. Pada setiap akhir siklus diberikan tes untuk mengukur ketercapaian hasil belajar siswa sebagai dampak dari tindakan yang diberikan.

Hasil pelaksanaan penelitian dideskripsikan berdasarkan data hasil belajar siswa pada tahap pra siklus, siklus I, dan siklus II. Deskripsi data hasil belajar siswa berdasarkan masing-masing tahapan seperti pada tabel berikut.

Tabel 2. Gambaran Hasil Belajar Siswa

\begin{tabular}{|l|c|c|}
\hline \multirow{2}{*}{ Tahapan } & \multicolumn{2}{|c|}{ Nilai } \\
\cline { 2 - 3 } & Rata-rata & Ketuntasan (\%) \\
\hline Pra Siklus & 45,63 & 33,33 \\
\hline Siklus I & 78,21 & 54,17 \\
\hline Siklus II & 80,33 & 83,33 \\
\hline
\end{tabular}

Sumber: Pengolahan Data penelitian

Data di atas menunjukkan bahwa rata-rata tes hasil belajar pada pra siklus sebesar 45,67 dan meningkat menjadi 78,23 pada siklus I dan pada siklus II menjadi 80,24. Ditinjau dari ketuntasan klasikal dapat diketahui bahwa pada akhir siklus ketuntasan siswa di atas $80 \%$ yaitu sebsar 83,33\% (20 siswa) yang memiliki nilai di atas KKM.

Ditinjau dari hasil belajar siswa terjadi peningkatan yang signifikan nilai rata-rata hasil belajar siswa. Peningkatan tersebut dapat dilihat dari gambar grafik berikut.

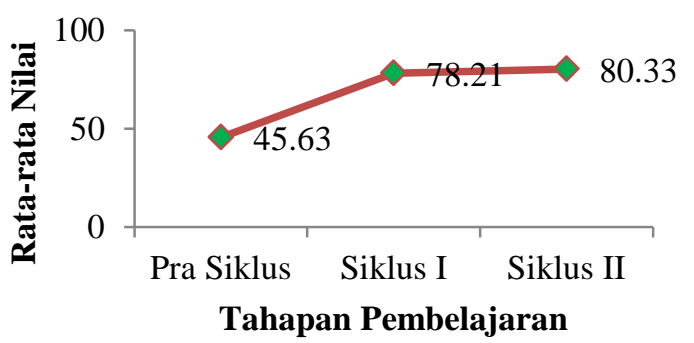

Gambar 1. Peningkatan hasil belajar siswa

Grafik di atas menunjukkan terjadi peningkatan rata-rata hasil belajar yang signifikan dari pra siklus yang meningkat pada siklus I. Peningkatan terjadi dari 45,63 menjadi 78,21 dan pada siklus II meningkat menjadi 80,33.

Deskripsi hasil penelitian berdasarkan tahapan pelaksanaan pembelajaran menggunakan model pembelajaran quided inquiry diuraikan sebagai berikut.

\section{b. Pembahasan}

Pelaksanaan tindakan pada siklus I dilakukan berdasarkan hasil analisis dari kegiatan observasi awal. Melalui temuan dari observasi awal tersebut diterapkan tindakan sebagai penyelesaian permasalahan.
1) Melaksanakan pembelajaran dengan mengulang kembali materi apersepsi agar siswa mudah menjembatani siswa dalam memahami materi pelajaran. Materi apersepsi tentang perbandingan trigonometri pada sudut istimewa.

2) Menerapkan pembelajaran berdasarkan RPP yang disusun dengan tahapan pembelajaran quided inquiry, yaitu: (1) engage, (2) explore, (3) explain, (4) elaborate, dan (5) evaluate.

3) Pengelompokan siswa didasarkan dari hasil tes awal pada pra siklus. Siswa dibagikan secara homogen yang berdasarkan tingkat kemampuan dari hasil tes.

4) Dalam pembelajaran siswa belajar dengan dituntun melalui LKPD yang telah didesain dengan pembelajaran quided inquiry. Guru berperan sebagai fasilitator dan melakukan pembimbingan dalam penemuan konsep.

Hasil atau capaian serta temuan dari tindakan siklus I dijadikan acuan dalam melakukan tindakan pada siklus II. Berdasarkan analisis hasil penelitian hal-hal yang telah dicapai pada siklus I, diantaranya ketuntasan klasikal siswa telah menacapai 54,17 artinya sudah lebih dari setengah siswa memiliki nilai di atas KKM. Hal ini berarti pemahaman siswa terhadap materi atau ketercapaian pembelajaran quided inquiry telah lebih dari $50 \%$.

Beberapa temuan sebagai refleksi pada siklus I, yaitu (1) siswa masih mengalami kesulitan dalam memahami masalah (tahap engage). Hal ini dikarenakan permasalahan yang diberikan belum menggunakan masalah nyata yang mudah dipahami siswa. (2) Siswa masih sulit dalam tahap menemukan konsep (explain), dimana sebagian siswa hanya menunggu bantuan dari guru dalam merancang penemuan. (3) sebagian siswa pada siklus I cendrung tidak berani menyajikan hasil di depan kelas, (4) siswa masih kesulitan mengamati penyajian LKPD.

Berdasarkan refleksi tersebut, disusun perecanan tindakan siklus II untuk mengatasi hal-hal yang belum tercapai pada siklus I. Rancangan tindakan tersebut juga didasari dari hasil analisis tes akhir siklus I yang telah dikerjakan oleh siswa. Tindakan yang dilakukan pada siklus II berdasarkan hasil refleksi siklus I adalah: (1) mendesaian permasalahan dengan menggunakan masalahmasalah nyata, (2) mendesain tahapan penemuan dalam LKPD dengan memberikan panduan dan tuntunan yang lebih runtun (3) memberikan motivasi kepada siswa untuk dapat melakukan penyajian di depan kelas, (4) memotivasi siswa untuk 
mempersentasikan hasil kerja di kelas, (5) melakukan perbaikan pada LKPD yang masih sulit digunakan oleh siswa.

Hasil pengamatan dari pelaksanaan tindakan siklus II ditinjau dari ketercapaian hasil belajar secara klasikal telah mencapai 83,33\%. Hal ini berarti 20 orang siswa telah memiliki nilai di atas KKM yang ditentukan sekolah yaitu 75. Selain itu, pada tahapan evaluasi siswa telah berani menyajikan jawaban di depan kelas dan terbentuk diskusi.

Hasil penelitian menunjukkan adanya peningkatan hasil belajar dengan diterapkan tahapan pembelajaran quided inquiry melalui perbaikanperbaikan dari hasil refleksi. Hasil penelitian ini sejalan dengan penelitian yang dilakukan oleh Kholik, Holisin, \& Kristanti (2016); Astuti, Joharman, \& Suript (2017), yang menunjukkan adanya peningkatan hasil belajar metamatika dengan pembelajaran quided inquiry.

Selain itu, hasil penelitian yang dilakukan oleh Sukmawati \& Sukadasih (2014) yang menunjukan bahwa rata-rata peningkatan kemampuan penalaran matematis siswa yang belajar dengan model pembelajaran inkuiri terbimbing lebih tinggi dibandingkan dengan siswa yang belajar dengan pembelajaran konvensional. Hasil penelitian terdahulu ini mendukung hasil penelitian yang dilakukan dimana model pembelajaran quided inquiry jika diterapkan dengan baik dapat memberikan peningkatan terhadap hasil belajar siswa.

\section{PENUTUP}

\section{a. Kesimpulan}

Penerapan model pembelajaran quided inquiry dapat meningkatkan hasil belajar siswa Kelas X-IBB SMA Negeri 1 Bengkulu Tengah. Peningkatan terjadi pada materi Penerapan Trigonometri dalam permasalahan nyata. Peningkatan hasil belajar terjadi dari pra siklus, siklus I, dan siklus II. Peningkatan tersebut dengan melakukan tindakan dari hasil refleksi dan temuan pada setiap siklus sebelumnya dengan menerapkan langkah quided inquiry. Tindakan yang dilaksanakan dalam meningkatkan hasil belajar yaitu: (1) pada tahap engage siswa dituntun untuk memahami permasalahan dan membuat pertanyaan yang relevan. (2) Tahap explore mendorong siswa untuk lebih mengekplorasi kemampuan melalui kegiatan pada LKPD, (3) tahap eksplain dapat melatih siswa dalam merancang perencanaan penyelesaian masalah, (4) tahap elaborasi dapat meningkat kepercayaan diri siswa dalam menyampaikan hasil diskusi, (5) tahap evaluate dapat memberikan penekanan pemahaman siswa terhadap materi yang diajarkan dalam pembelajaran.

Peningkatan hasil belajar matematika siswa dalam pembelajaran matematika ditunjukkan dari data pra siklus yang secara kelasikal hanya sebesar $33,33 \%$ dan menngkat pada siklus I menjadi $54,17 \%$. Setelah dilakukan perbaikan pada akhir siklus I berdasarkan refleksi terjadi peningkatan pada siklus II dimana ketuntasan belajar telah sesuai dengan kriteria tindakan yaitu sebesar $83,33 \%$.

\section{b. Implikasi}

Penelitian ini diharapkan memberi implikasi bagi beberapa pihak, yaitu:

1. Siswa. Mendapat pengalaman pembelajaran menggunakan pembelajaran guided inquiry sehingga kemampuan siswa meningkat dalam memahami materi trigonometri.

2. Guru. Memperoleh pengalaman dalam proses pembelajaran, khususnya dalam menggunakan model pembelajaran guided inquiry dalam pembelajaran matematika. Dapat dijadikan acuan oleh guru lain dalam memilih model pembelajaran yang sesuai.

3. Sekolah. Mendapat informasi kemampuan siswa, sehingga dapat dilakukan tindakan dalam upaya meningkatkan kualitas pembelajaran matematika khususnya ketercapaian hasil belajar matematika.

\section{c. Saran}

Berdasarkan kajian hasil penelitian yang telah maka dapat dibuat beberapa saran penelitian.

1. Dalam pelaksanaan pembelajaran dengan menggunakan model pembelajaran quided inquiry guru hendaknya menyusun Lembar Kerja Peserta Didik (LKPD) untuk memfasilitasi siswa dalam mengikuti pembelajaran. Dalam melakukan tahapan pembelajaran siswa dapat dipandu dengan LKPD

2. Dalam menyusun bahan ajar hendaknya guru menggunakan masalah nyata sehingga dalam pelaksanaan penelitian siswa lebih mudah dalam proses pembelajaran dan menemukan konsep.

3. Dalam pembelajaran guru hendaknya menyediakan pertanyaan yang relevan dengan tujuan penyampaian materi, sehingga jika pertanyaan tidak muncul dari siswa guru dapat membimbing siswa

4. Pembentukan kelompok kecil dalam membantu pelaksanaan pembelajaran sangat diperlukan 


\section{DAFTAR PUSTAKA}

Abidin, Y. 2013. Desain sistem pembelajaran dalam konteks kurikulum 2013. Bandung: PT Refika Aditama

Astuti, Joharman, \& Suript. 2017. Penerapan model inkuiri terbimbing dengan media konkret untuk meningkatkan hasil belajar matematika tentang bangun datar pada siswa Kelas VB sd Negeri 1 Sidoharum taHun Ajaran 2016/2017. Kalam Cendekia, Vol (5), (4), 2017, 319-323

Arikunto, Suharsimi. 2009. Prosedur Penelitian. Jakarta: Rineka Cipta

Depdiknas. 2006. Panduan Pengembangan Bahan Ajar. Departemen Pendidikan Nasional Direktorat Jenderal Manajemen Pendidikan Dasar dan Menengah

Kholik, A., Holisin, \& Kristanti. 2016. peningkatan hasil belajar matematika melalui model pembelajaran kooperatif tipe guided inquiry pokok bahasan garis singgung lingkaran pada siswa madrasah tsanawiyah. Journal of Mathematics Education, Science and Technology, Vol. 1 (1), 2016, 1 - 9

Iskandar. 2009. Penelitian Tindakan Kelas. Jambi: Gaung Persada Press

Joyce, B. \& Weil, M. (1992). Models of teaching. New Jersey: Prentice Hallmuhajirin

Kemendikbud. (2014). Peraturan Menteri Pendidikan dan Kebudayaan Nomor 59, Tahun 2013, tentang Kerangka Dasar dan Struktur Kurikulum Sekolah Menengah Atas/Madrasah Aliyah.

Kuhlthau, C. 2007. Guided inquiry: Learning in the $21^{\text {st }}$ century School. New York: Libraries Unlimited, Inc.

Mendiknas. (2006). Peraturan Menteri Pendidikan Nasional Nomor 23, Tahun 2006, tentang Standar Kompetensi Lulusan untuk Satuan Pendidikan Dasar dan Menengah.

Moore, K. D. 2009. Effective instructional strategies, from theory to practice. Thousand Oaks: SAGE.

Praptiwi, Sarwi, \& Handayani. 2012. efektivitas model pembelajaran eksperimen inkuiri terbimbing berbantuan my own dictionary untuk meningkatkan penguasaan konsep dan unjuk kerja siswa SMP RSBI. Unnes Science Education Journal, Vol 1 (2), 2012, 1-8

Rusdi, Maulidiya, \& Susanto. 2013. Pembelajaran inkuiri pada materi trigonometri untuk meningkatkan hasil belajar dan aktifitas siswa Kelas X2 SMAN 1 Kota Bengkulu. Prosiding Semirata FMIPA Universitas Lampung, 2013

Sefriyan, D. Caswita, \& Coesamin, M. 2013. Pengaruh penerapan metode inkuiri terbimbing terhadap motivasi, aktivitas dan hasil belajar siswa. Jurnal pendidikan matematika, Volume 2, Nomor 1, Februari 2013

Sukmawati \& Sukadasih. 2014. Penerapan model pembelajaran inkuiri terbimbing alam pembelajaran matematika untuk meningkatkan kemampuan penalaran matematis siswa SMK. EDU-MAT Jurnal Pendidikan Matematika, Vol (2), (3), 2014, 202-210 